\title{
Phase Formation and Microstructure Evolution of Al-5Si-0.8Mg Alloys with Different Mn Concentrations
}

\author{
Ni Tian ${ }^{1,2, *}$, Guangdong Wang ${ }^{1}\left(\mathbb{D}\right.$, Yiran Zhou ${ }^{1}$, Chuncheng Liu ${ }^{3}$, Kun Liu ${ }^{4}{ }^{(}$, , Gang Zhao ${ }^{1,2}$ and Liang Zuo ${ }^{2}(\mathbb{D}$ \\ 1 School of Materials Science \& Engineering, Northeastern University, No. 3-11, Wenhua Road, Heping District, \\ Shenyang 110819, China; w15041838726@163.com (G.W.); zhouyr@mail.neu.edu.cn (Y.Z.); \\ zhaog@mail.neu.edu.cn (G.Z.) \\ 2 Key Laboratory for Anisotropy and Texture of Materials (Ministry of Education), Northeastern University, \\ No. 3-11, Wenhua Road, Heping District, Shenyang 110819, China; lzuo@mail.neu.edu.cn \\ 3 Engineering Training Center, Northeastern University, No. 3-11, Wenhua Road, Heping District, \\ Shenyang 110819, China; liuccsy@sina.com \\ 4 Department of Applied Science, University of Quebec at Chicoutimi, 555, Boul. de L'university, \\ Chicoutimi, QC G7H2B1, Canada; kun.liu@uqac.ca \\ * Correspondence: tiann@atm.neu.edu.cn; Tel.: +86-024-83691571
}

Citation: Tian, N.; Wang, G.; Zhou, Y.; Liu, C.; Liu, K.; Zhao, G.; Zuo, L. Phase Formation and Microstructure Evolution of Al-5Si-0.8Mg Alloys with Different Mn Concentrations. Metals 2021, 11, 308. https:// doi.org/10.3390/met11020308

Academic Editor: Elisabetta Gariboldi Received: 21 January 2021

Accepted: 6 February 2021

Published: 10 February 2021

Publisher's Note: MDPI stays neutral with regard to jurisdictional claims in published maps and institutional affiliations.

Copyright: (c) 2021 by the authors. Licensee MDPI, Basel, Switzerland. This article is an open access article distributed under the terms and conditions of the Creative Commons Attribution (CC BY) license (https:/ / creativecommons.org/licenses/by/ $4.0 /)$.

\begin{abstract}
Mg-containing high-Si aluminum alloys are heat-treatable alloys that are widely used in industry. Substantial attention has been paid to increasing the performance of such alloys by adding a small amount of $\mathrm{Mn}$, which is an effective and common alloying element in aluminum alloys. In the present work, the solidification process of $\mathrm{Mn}$-free Al-5Si-0.8Mg alloy and Al-5Si-0.8Mg- $(0.45-$ 1.97)Mn alloys are analyzed by the experimental results combined with thermodynamic calculation. The results showed that $\alpha-\mathrm{Al}, \mathrm{Si}, \mathrm{Mg}_{2} \mathrm{Si}$ and $\pi\left(\mathrm{Al}_{8} \mathrm{Mg}_{3} \mathrm{FeSi}_{6}\right)$ are predominant phases in the Mn-free Al-5Si-0.8Mg alloy while the $\pi\left(\mathrm{Al}_{8} \mathrm{Mg}_{3} \mathrm{FeSi}_{6}\right)$ phase are transformed to $\alpha$-Al(FeMn)Si phase with the addition of $0.45 \% \mathrm{Mn}$. With increasing $\mathrm{Mn}$ addition to $0.72 \%$, the $\mathrm{L} \rightarrow \alpha-\mathrm{Al}$ was replaced by $\mathrm{L} \rightarrow \alpha-\mathrm{Al}(\mathrm{FeMn}) \mathrm{Si}$ and a primary $\alpha-\mathrm{Al}(\mathrm{FeMn}) \mathrm{Si}$ phase appeared. Further increasing the Mn to $1.97 \%$, the solidification reactions remained unchanged. However, the size and number of the primary $\alpha-\mathrm{Al}(\mathrm{FeMn}) \mathrm{Si}$ phase gradually increased, while the divorced eutectic phenomenon of quaternary eutectic structure gradually weakened. Meanwhile, the $\mathrm{Mg}_{2} \mathrm{Si}$ phase in the quaternary eutectic structure gradually transformed from blocky to fine eutectic lamellar, and the quaternary eutectic structure was significantly refined. Primary blocky $\alpha-\mathrm{Al}(\mathrm{FeMn}) \mathrm{Si}$ began to form when the Mn content was higher than $0.75 \%$.
\end{abstract}

Keywords: Al-5Si-0.8Mg alloy; Mn content; solidification process; thermodynamic calculation

\section{Introduction}

In recent years, Al-Si alloys have been widely used in engines within the automotive and aerospace industries because of their high specific strength, high wear resistance, high corrosion resistance, low thermal expansion coefficient, low cost and excellent casting performance, making these alloys incomparable to other aluminum alloys [1-4]. Combinations of $\mathrm{Al}$, Si and other elements is an effective and easy way to modify material performance and expand the use of an alloy. Mn is an effective and common alloying element in aluminum alloys [5,6]. Substantial attention has been paid to increasing the performance of aluminum alloys by adding small amounts of Mn. Qiu et al. [7] found that the addition of $\mathrm{Mn}$ could transform the $\beta-\mathrm{Al}_{5} \mathrm{FeSi}$ phase into the $\alpha-\mathrm{Al}(\mathrm{MnFe}) \mathrm{Si}$ phase in Al-7Si-0.3Mg, and with an increase in Mn content, the morphology of the $\alpha-\mathrm{Al}(\mathrm{MnFe}) \mathrm{Si}$ phase gradually changed from dendritic to rod shaped and finally to a "Chinese script" shape. Huang et al. [8] found that, when Mn was added to spray-deposited Al-25Si-xFe alloy, $\alpha-\mathrm{Al}_{15}(\mathrm{FeMn})_{3} \mathrm{Si}_{2}$ was formed, which replaced the $\delta-\mathrm{Al}_{4} \mathrm{FeSi}_{2}$ and $\beta-\mathrm{Al}_{5} \mathrm{FeSi}$ phases and, subsequently, changed the morphology of the Fe phase in the alloy. Seifeddine et al. [9] 
studied the Al-9Si-0.3Fe-(0-1.01)Mn alloy and reported that increasing the Mn content together with the solidification rates will change the amount and morphology of Fe-rich intermetallics. At Mn:Fe of 2:1, the formation of needle-like Fe-rich intermetallics are still not totally depleted. At low Mn concentrations but high cooling rates, the formations of Fe-rich intermetallics tend to be suppressed to some extent. However, at higher Mn concentrations, the Chinese-script Fe-rich intermetallics seem to be primary precipitated and embedded within the dendrites. Hwang et al. [10] determined that increasing the Mn content transformed the needle-like $\beta$ phase into the Chinese script-like $\alpha$ phase in an Al-7Si-3.8Cu-0.5Fe alloy, which improved the strength of the alloy while retaining the same plasticity. It is reported that the tensile strength increased from $328 \mathrm{MPa}$ in Mn-free alloy to the highest $360 \mathrm{MPa}$ with $0.65 \% \mathrm{Mn}$, but it decreased to $348 \mathrm{MPa}$ with further addition of $\mathrm{Mn}(0.85 \% \mathrm{Mn})$. Therefore, the addition of Mn can change the morphology of the Fe-containing crystalline phase and improve the mechanical properties of the alloy. This is consistent with relevant research results [11,12]. Lu et al. [13] noted that Mn mainly existed in the form of an $\mathrm{Al}_{7}(\mathrm{MnFeSi})_{3}$ blocky phase (size > 50 microns) in the $\mathrm{Al}-17 \mathrm{Si}-2 \mathrm{Fe}-2 \mathrm{Cu}-1 \mathrm{Ni}$ alloy. Lin et al. [14] observed that when the Mn content reached $0.8 \%$, the $\alpha-\mathrm{Al}_{15}(\mathrm{FeMn})_{3} \mathrm{Si}_{2}$ phase (size $\approx 50$ microns) appeared in the Al-17Si-2Fe-2Cu-1Ni alloy. In addition, the primary micro-scale Mn-containing phase in the Al-9Si-3Cu-(0.8-1.2)Fe-(0.25-0.55)Mn and Al-9Si-3Cu-(0.75-1.62)Fe-(0.55-0.79)Mn alloy studied by S. Ferraro et al. [15] and Timelli et al. [16] was also observed. According to the above research, Mn can also exist in the form of a large alloy phase with a size of several tens of microns in aluminum alloy. On the other hand, Liu et al. [17] and Yan et al. [18] investigated Al-(1.09-1.93)Mg-(0.4-0.58)Si-0.27Mn alloy and $\mathrm{Al}-0.66 \mathrm{Mg}-0.85 \mathrm{Si}-0.1 \mathrm{Mn}$ alloy, respectively, and found that the $\mathrm{Mn}$ in the ingots mainly existed in the form of insoluble $\mathrm{Al}_{15}(\mathrm{FeMn})_{3} \mathrm{Si}_{2}$ dispersed phase particles. When Lee et al. [19] studied extruded Al-0.66Mg-0.8Si-1.0Mn alloy and Han et al. [20] studied Al$0.74 \mathrm{Mg}-0.96 \mathrm{Si}-0.5 \mathrm{Cu}-0.6 \mathrm{Mn}$ and $\mathrm{Al}-1.08 \mathrm{Mg}-1.27 \mathrm{Si}-0.42 \mathrm{Cu}-0.6 \mathrm{Mn}$ alloy plates, they found that Mn mainly existed in the form of dispersed phase particles in the experimental alloys, effectively pinning dislocations and subgrain boundaries, inhibiting recrystallization during deformation, and improving the strength and plasticity of the alloy.

In conclusion, the current research on the role of $\mathrm{Mn}$ in Mg-containing high-Si aluminum alloys have mainly focused on the second phase formed by Mn in Al-Si alloys. The literature shows that Mn mainly exists in the form of a coarse alloy phase (size: tens or even hundreds of microns), a eutectic structure (size: tens of microns) and dispersed phase particles (size: hundreds of nanometers) in aluminum alloys. However, there are few studies on the influence of Mn content on the microstructure of high-Si aluminum alloys, especially on the impact of the variation in $\mathrm{Mn}$ content on the solidification process of Al-Si alloys.

In this paper, the transformation of the type, morphology, size and quantity of the second phases in an Al-5Si-0.8Mg alloy ingot with different Mn contents were observed, and the solidification process of the phases and microstructures were analyzed in combination with the phase diagram and thermodynamic analysis. This study provides data for optimizing the composition and improving the overall performance of Mn-containing Al-Si-Mg alloy by controlling the microstructure.

\section{Materials and Methods}

The experimental alloys were prepared from commercially pure $\mathrm{Al}(99.7 \%)$, electrolytic grade copper, commercially pure $\mathrm{Mg}$, an $\mathrm{Al}-30 \mathrm{Si}$ master alloy and an $\mathrm{Al}-10 \mathrm{Mn}$ master alloy. These raw materials were melted in an electrical resistance crucible furnace and cast into ingots with a water-cooled copper mold $\left(180 \times 100 \times 30 \mathrm{~mm}^{3}\right)$. The compositions of the alloy ingots used in the present study are shown in Table 1. 
Table 1. Compositions of the alloy ingots in the present study (mass \%).

\begin{tabular}{cccccc}
\hline No. & Mg & Si & Mn & Fe & Al \\
\hline 1 & 0.78 & 5.64 & - & 0.19 & Bal. \\
2 & 0.79 & 5.21 & $\mathbf{0 . 4 5}$ & 0.18 & Bal. \\
3 & 0.80 & 4.99 & $\mathbf{0 . 7 2}$ & 0.16 & Bal. \\
4 & 0.83 & 4.95 & $\mathbf{1 . 0 9}$ & 0.17 & Bal. \\
5 & 0.75 & 4.97 & $\mathbf{1 . 6 5}$ & 0.12 & Bal. \\
6 & 0.75 & 4.96 & $\mathbf{1 . 9 7}$ & 0.12 & Bal. \\
\hline
\end{tabular}

Specimens with dimensions of $10 \times 10 \times 15 \mathrm{~mm}^{3}$ were cut from the six alloys at the same core position, as shown in Figure 1. The samples for metallurgical observation with $\mathrm{OM}$ and SEM are first grinded by sandpapers until to \#2000 grit and then mechanical polished with suspensions of $0.5 \mu \mathrm{m}$.

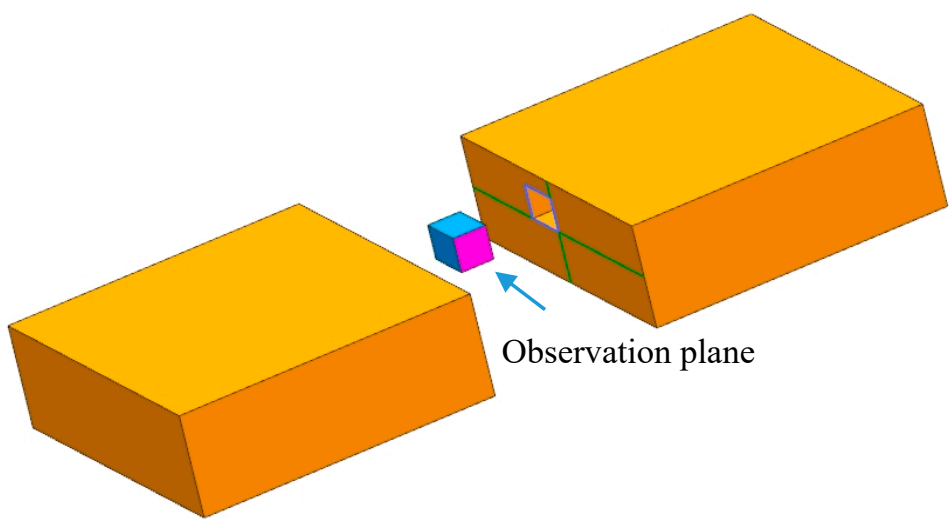

Figure 1. Sketch of metallographic specimens cutting from the cross section of ingot (the pink surface was the observation surface).

The microstructure was observed with an Olympus GX71 optical microscope (Olympus Corporation, Tokyo, Japan), and the observed surface was perpendicular to the direction with the maximum cooling gradient. Phase analysis was performed by an $X^{\prime}$ Pert Pro MPD (Panalytical, Eindhoven, Holland) X-ray Diffraction system with the test conditions of $\mathrm{Cu} K \alpha$ rays, scanning rate $2^{\circ} / \mathrm{min}$, step size $0.02^{\circ}$, tube voltage $40 \mathrm{kV}$, and tube current $40 \mathrm{~mA}$. The morphology of the second phases in the alloy was examined with a JSM 6510 scanning electron microscope, equipped with an energy-dispersive spectrometer (JEOL Ltd., Tokyo, Japan). In addition, the solidification simulation function in Pandat software (CompuTherm LLC, Middleton, WI, USA, 2016 version) was used to predict the non-equilibrium solidification processes of the experimental alloys. The Gulliver-Scheil model is used to simulate non-equilibrium solidification calculation.

\section{Results and Discussion}

\subsection{Effect of Mn Contents on the Microstructure of Al-5Si-0.8Mg Alloy}

The as-cast microstructures of Al-5Si-0.8Mg free of Mn and Al-5Si-0.8Mg-(0.45-1.97)Mn (mass fraction, \%) alloy ingots are shown in Figure 2. The figure shows there are many white $\alpha$-Al dendrites and many needle-like and flake-like gray or dark-gray phases, which are all distributed along the grain boundaries or interdendritically (Figure 2a, dashed rectangular area) in the Mn-free Al-5Si-0.8Mg alloy ingot. With the addition of $\mathrm{Mn}$, the number of light needle-like or blocky alloy phases in the alloy increases (Figure 2b,c, dashed rectangular area). Moreover, the eutectic microstructure of the alloy ingots is slightly refined. When the content of Mn reaches $0.72 \%$, light-gray skeletal phases (size: approximately $20 \mu \mathrm{m}$ ) appear in the alloy ingots (Figure 2c, dashed rectangular area). When the Mn content reaches $1.09 \%$, blocky alloy phases (size: approximately $50 \mu \mathrm{m}$ ) appear in the ingot (Figure $2 \mathrm{~d}$, dashed rectangular area), and the eutectic lamellar structure of the alloy ingot is further 
refined. Finally, as the Mn content increased from 1.09\% to 1.97\%, the number of blocky alloy phases increased, but the eutectic lamellar structure did not change significantly.
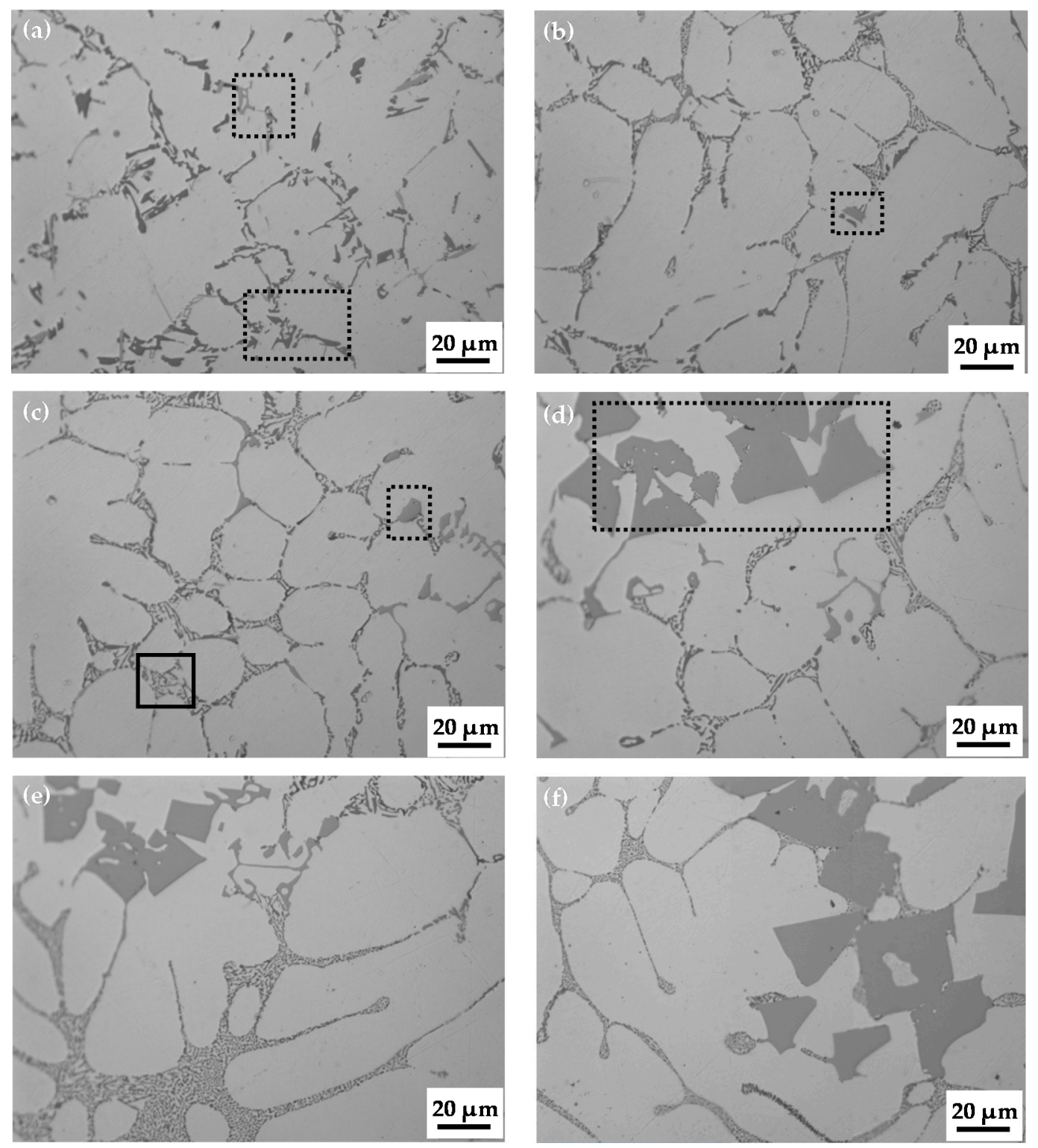

Figure 2. Microstructures of Al-5Si-0.8Mg alloy ingots (a) without Mn and those with (b) $0.45 \% \mathrm{Mn}$, (c) $0.72 \% \mathrm{Mn},(\mathbf{d}) 1.09 \%$ $\mathrm{Mn},(\mathbf{e}) 1.65 \% \mathrm{Mn}$, and (f) $1.97 \% \mathrm{Mn}$.

\subsection{Evolution of the Phases with Mn Additions}

Figure 3 shows the X-ray diffraction (XRD) patterns of Al-5Si-0.8Mg ingots free of $\mathrm{Mn}$ and those with $0.45 \% \mathrm{Mn}, 0.72 \% \mathrm{Mn}, 1.09 \% \mathrm{Mn}$, and $1.97 \% \mathrm{Mn}$. The figure shows that there are mainly four types of alloy phases existing in Al-5Si-0.8Mg ingots without $\mathrm{Mn}: \alpha-\mathrm{Al}$, Si phase, $\pi$ phases $\left(\mathrm{Al}_{8} \mathrm{Mg}_{3} \mathrm{FeSi}_{6}\right)$ and $\mathrm{Mg} 2 \mathrm{Si}$ phases. The structure of $\pi\left(\mathrm{Al}_{8} \mathrm{Mg}_{3} \mathrm{FeSi}_{6}\right)$ is hexagonal P-62m space group with the lattice parameter of $a$ as $0.66 \mathrm{~nm}$ and $c$ as $0.79 \mathrm{~nm}$. When Mn was added to the Al-5Si-0.8Mg alloys, the intensity of the diffraction peak of the $\pi$ phase $\left(\mathrm{Al}_{8} \mathrm{Mg}_{3} \mathrm{FeSi}_{6}\right)$ weakened and nearly disappeared. Moreover, diffraction peaks of the $\alpha-\mathrm{Al}(\mathrm{FeMn}) \mathrm{Si}$ phases appeared in the XRD patterns of the alloy ingots. With the further increase in Mn contents, the number of diffraction peaks of the $\alpha-\mathrm{Al}(\mathrm{FeMn}) \mathrm{Si}$ phases increased, and the intensity of those peaks increased. The intensity of the $\mathrm{Mg}_{2} \mathrm{Si}$ phase diffraction peaks also increased with increasing Mn. According to the above results, 
there are mainly $\alpha-\mathrm{Al}$, Si phases, $\alpha-\mathrm{Al}(\mathrm{FeMn}) \mathrm{Si}$ phases and $\mathrm{Mg}_{2} \mathrm{Si}$ phases existing in $\mathrm{Mn}$ containing Al-5Si-0.8Mg alloy ingots. The structure of the $\alpha-\mathrm{Al}(\mathrm{FeMn}) \mathrm{Si}$ phase is bcc with $\operatorname{Im} 3$ space group with the lattice parameter of $a$ as $1.25 \mathrm{~nm}$.

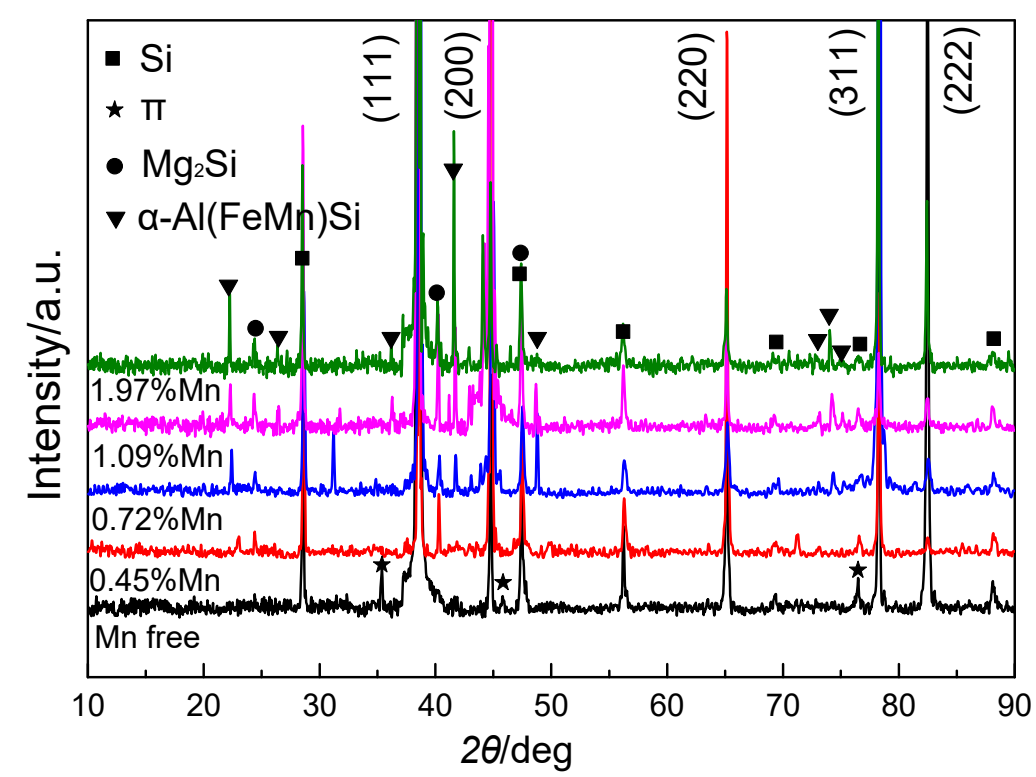

Figure 3. XRD patterns of Al-5Si-0.8Mg alloy ingots without Mn and those with $0.45 \% \mathrm{Mn}, 0.72 \% \mathrm{Mn}$, $1.09 \% \mathrm{Mn}$, and $1.97 \% \mathrm{Mn}$.

Scanning electron microscopy (SEM) images of Al-5Si-0.8Mg alloy ingots without $\mathrm{Mn}$ and those with $0.45 \% \mathrm{Mn}$ and $1.09 \% \mathrm{Mn}$ are shown in Figure 4, and the energy-dispersive spectroscopy (EDS) results of the various alloy phases (indicated by arrow and number) in Figure 4 are summarized in Table 2. According to the XRD results in Figure 3 and the EDS analysis results in Table 2, the gray needle-flake phases in the Al-5Si-0.8Mg alloy were eutectic Si phases (Figure 4a, point 1). The results show that there are inhomogeneous black blocky or skeletal $\mathrm{Mg}_{2} \mathrm{Si}$ phases (Figure 4a, point 2) and bright white needle-like or blocky $\pi$ phases $\left(\mathrm{Al}_{8} \mathrm{Mg}_{3} \mathrm{FeSi}_{6}\right.$ ) (Figure $4 \mathrm{a}$, point 3 ) in the $\mathrm{Al}-5 \mathrm{Si}-0.8 \mathrm{Mg}$ alloy without $\mathrm{Mn}$. When $\mathrm{Mn}$ was added to the experimental alloy, there were rarely any $\pi$ phases $\left(\mathrm{Al}_{8} \mathrm{Mg}_{3} \mathrm{FeSi}_{6}\right)$ existing in the alloy. Instead, the Mn-containing alloys had $\alpha-\mathrm{Al}(\mathrm{FeMn}) \mathrm{Si}$ phases that are a few microns to a few dozen microns in size (Figure $4 \mathrm{~b}$, point 4 and point 5). These results are consistent with the $\mathrm{XRD}$ results. The eutectic structure of the alloy was refined. When the Mn content reached $1.09 \%$, massive $\alpha-\mathrm{Al}(\mathrm{FeMn}) \mathrm{Si}$ phases that are several tens of microns thick appear in the alloy (Figure 4a, point 6). In addition, the black $\mathrm{Mg}_{2} \mathrm{Si}$ phases in the alloy changed from medium-sized blocky or skeletal morphologies to a smaller uniformly distributed pin-shaped morphology, for which the number increased significantly.
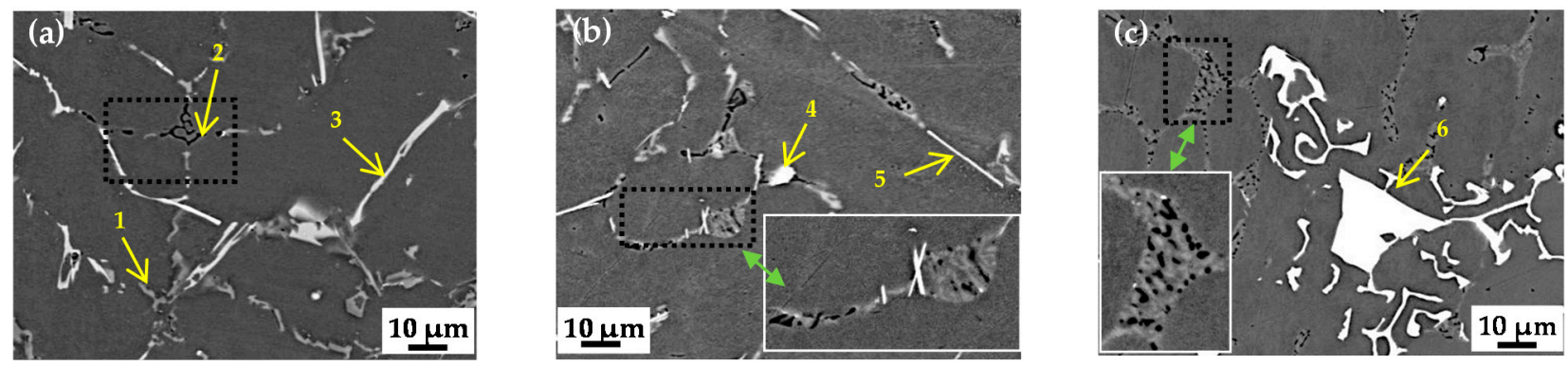

Figure 4. SEM images of Al-5Si-0.8Mg alloy ingots (a) without Mn and those with (b) $0.45 \% \mathrm{Mn}$ and (c) $1.09 \% \mathrm{Mn}$. 
Table 2. EDS results of the points in Figure 4 (Atomic \%).

\begin{tabular}{cccccc}
\hline Points & Al & Si & Fe & Mg & Mn \\
\hline 1 & 18.56 & 81.44 & - & - & - \\
2 & 69.35 & 18.57 & - & 12.08 & - \\
3 & 56.49 & 23.82 & 4.51 & 15.18 & - \\
4 & 81.31 & 12.57 & 1.70 & - & 4.42 \\
5 & 49.86 & 34.65 & 10.81 & - & 4.68 \\
6 & 71.89 & 10.50 & 0.79 & - & 16.82 \\
\hline
\end{tabular}

\subsection{Effect of Mn Contents on the Solidification Behavior of the Al-5Si-0.8Mg Alloy}

The solidification curves of experimental alloys under non-equilibrium (GulliverScheil model) condition were calculated by Pandat software, and the results were shown in Figure 5 and also summarized in Table 3. It can be seen that there are $\mathrm{Al}, \mathrm{Si}, \mathrm{Al}_{8} \mathrm{Mg}_{3} \mathrm{FeSi}_{6}$ and $\mathrm{Mg}_{2} \mathrm{Si}$ phases precipitating from liquid phase during the solidification of $\mathrm{Mn}$-free Al-5Si-0.8Mg alloy. However, in addition to the $\mathrm{Al}, \mathrm{Si}, \mathrm{Al}_{8} \mathrm{Mg}_{3} \mathrm{FeSi}_{6}$ and $\mathrm{Mg}_{2} \mathrm{Si}$ phases, there is also $\alpha-\mathrm{Al}(\mathrm{FeMn}) \mathrm{Si}$ precipitating from the liquid with the addition of $0.45 \% \mathrm{Mn}$. Additionally, the model calculation showed that the mass fraction of $\mathrm{Al}_{8} \mathrm{Mg}_{3} \mathrm{FeSi}_{6}$ phase was only $0.001 \%$. This means that the $\mathrm{Al}_{8} \mathrm{Mg}_{3} \mathrm{FeSi}_{6}$ phase almost disappeared and the eutectic $\alpha-\mathrm{Al}(\mathrm{FeMn}) \mathrm{Si}$ formed in $\mathrm{Al}-5 \mathrm{Si}-0.8 \mathrm{Mg}$ alloy when the Mn content increased to $0.45 \%$. Additionally, the primary $\alpha-\mathrm{Al}(\mathrm{FeMn}) \mathrm{Si}$ phase appeared in the alloy with the addition of $0.72 \% \mathrm{Mn}$. The type of alloy phases remained unchanged as the Mn content gradually increased to $1.97 \%$, which was completely consistent with the XRD results in Figure 3. According to the metallograph of the Al-5Si-0.8Mg-(0-1.97) Mn alloys in Figure 2, the solidification curves calculated by the thermodynamics in Figure 4 and the research results of Backerud [21], the solidification reactions of the six alloys with different $\mathrm{Mn}$ were concluded and are shown in Figure 5a-f and Table 3, respectively. In the solidification of $\mathrm{Mn}$-free Al-5Si-0.8Mg alloy, the $\alpha$-Al dendrite, $\left(\alpha-\mathrm{Al}+\mathrm{Al}_{5} \mathrm{FeSi}\right)$ binary eutectic, $\left(\alpha-\mathrm{Al}+\mathrm{Si}+\mathrm{Al}_{5} \mathrm{FeSi}\right)$ ternary eutectic, $\left(\alpha-\mathrm{Al}+\mathrm{Si}+\mathrm{Al}_{8} \mathrm{Mg}_{3} \mathrm{FeSi}_{6}\right)$ ternary eutectic and $\left(\alpha-\mathrm{Al}+\mathrm{Si}+\mathrm{Mg}_{2} \mathrm{Si}+\mathrm{Al}_{8} \mathrm{Mg}_{3} \mathrm{FeSi}_{6}\right)$ quaternary eutectic were obtained by $\mathrm{L} \rightarrow \alpha-\mathrm{Al}$ at $621.7^{\circ} \mathrm{C}, \mathrm{L} \rightarrow \alpha-\mathrm{Al}+\mathrm{Al}_{5} \mathrm{FeSi}$ at $580.8^{\circ} \mathrm{C}, \mathrm{L} \rightarrow \alpha-\mathrm{Al}+\mathrm{Si}+\mathrm{Al}_{5} \mathrm{FeSi}$ at $569.3^{\circ} \mathrm{C}, \mathrm{L}+\mathrm{Al}_{5} \mathrm{FeSi} \rightarrow \alpha-$ $\mathrm{Al}+\mathrm{Si}+\mathrm{Al}_{8} \mathrm{Mg}_{3} \mathrm{FeSi}_{6}$ at $559.7^{\circ} \mathrm{C}$ and $\mathrm{L} \rightarrow \alpha-\mathrm{Al}+\mathrm{Si}+\mathrm{Mg}_{2} \mathrm{Si}+\mathrm{Al}_{8} \mathrm{Mg}_{3} \mathrm{FeSi}_{6}$ at $554.2^{\circ} \mathrm{C}$, respectively. With the addition of $0.45 \% \mathrm{Mn}$, the $\mathrm{L} \rightarrow \alpha-\mathrm{Al}+\mathrm{Al}_{5} \mathrm{FeSi}$ and $\mathrm{L} \rightarrow \alpha-\mathrm{Al}+\mathrm{Si}+\mathrm{Al}_{5} \mathrm{FeSi}$ disappeared during solidification, whereas, $\mathrm{L} \rightarrow \alpha-\mathrm{Al}+\alpha-\mathrm{Al}(\mathrm{FeMn}) \mathrm{Si}$ and $\mathrm{L} \rightarrow \alpha-\mathrm{Al}+\mathrm{Si}+\alpha-$ $\mathrm{Al}(\mathrm{FeMn}) \mathrm{Si}$ occurred successively at about 616.3 and $568.3^{\circ} \mathrm{C}$, respectively. Although the $\mathrm{L}+\mathrm{Al}_{5} \mathrm{FeSi} \rightarrow \alpha-\mathrm{Al}+\mathrm{Si}+\mathrm{Al}_{8} \mathrm{Mg}_{3} \mathrm{FeSi}_{6}$ and $\mathrm{L} \rightarrow \alpha-\mathrm{Al}+\mathrm{Si}+\mathrm{Mg}_{2} \mathrm{Si}+\mathrm{Al}_{8} \mathrm{Mg}_{3} \mathrm{FeSi}_{6}$ reactions still presented in the solidification of $\mathrm{Al}-5 \mathrm{Si}-0.8 \mathrm{Mg}-0.45 \mathrm{Mn}$ alloy, the model calculation result showed that the mass fraction of $\mathrm{Al}_{8} \mathrm{Mg}_{3} \mathrm{FeSi}_{6}$ was only $0.001 \%$, indicating that there was almost no $\mathrm{Al}_{8} \mathrm{Mg}_{3} \mathrm{FeSi}_{6}$ phase when the $\mathrm{Mn}$ content was up to $0.45 \%$. The primary $\alpha-\mathrm{Al}(\mathrm{FeMn}) \mathrm{Si}$ phase (as shown in the dashed area in Figure 2c) was formed by $\mathrm{L} \rightarrow \alpha-\mathrm{Al}(\mathrm{FeMn}) \mathrm{Si}$ at $626.2^{\circ} \mathrm{C}$ when the Mn content increased to $0.72 \%$, and then $\mathrm{L} \rightarrow \alpha-\mathrm{Al}+\alpha-$ $\mathrm{Al}(\mathrm{FeMn}) \mathrm{Si}, \mathrm{L} \rightarrow \alpha-\mathrm{Al}+\mathrm{Si}+\alpha-\mathrm{Al}(\mathrm{FeMn}) \mathrm{Si}$ and $\mathrm{L} \rightarrow \alpha-\mathrm{Al}+\mathrm{Si}+\mathrm{Mg}_{2} \mathrm{Si}+\alpha-\mathrm{Al}(\mathrm{FeMn}) \mathrm{Si}$ reactions occurred successively at about $624.9,567.3$ and $553.8^{\circ} \mathrm{C}$. It was noticeable that the $\mathrm{L} \rightarrow \alpha-\mathrm{Al}$ reaction disappeared in $\mathrm{Al}-5 \mathrm{Si}-0.8 \mathrm{Mg}-0.72 \mathrm{Mn}$ alloy. No significant changes were observed in the solidification reactions as the increasing of Mn content from $0.72 \%$ to $1.97 \%$, except that the $\mathrm{L} \rightarrow \alpha-\mathrm{Al}(\mathrm{FeMn}) \mathrm{Si}$ reaction temperature gradually increased from 626.2 to $673.1^{\circ} \mathrm{C}$, as shown in Figure $5 \mathrm{c}-\mathrm{f}$ and Table 3 . Meanwhile, the size and quantity of the primary $\alpha-\mathrm{Al}(\mathrm{FeMn}) \mathrm{Si}$ phase gradually increased with the increasing in Mn (as shown in Figure $2 \mathrm{~d}-\mathrm{f})$. 


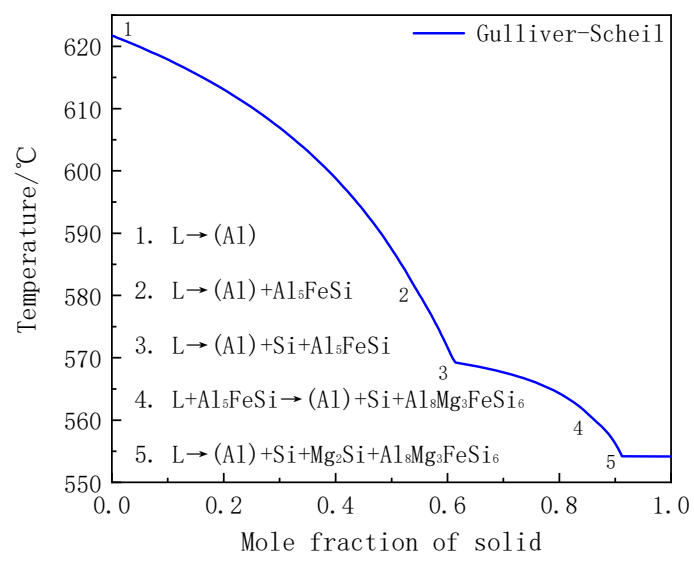

(a)

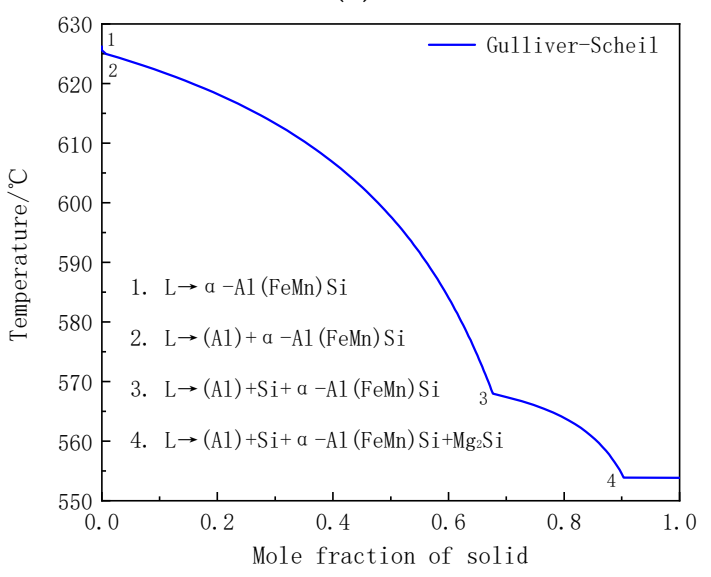

(c)

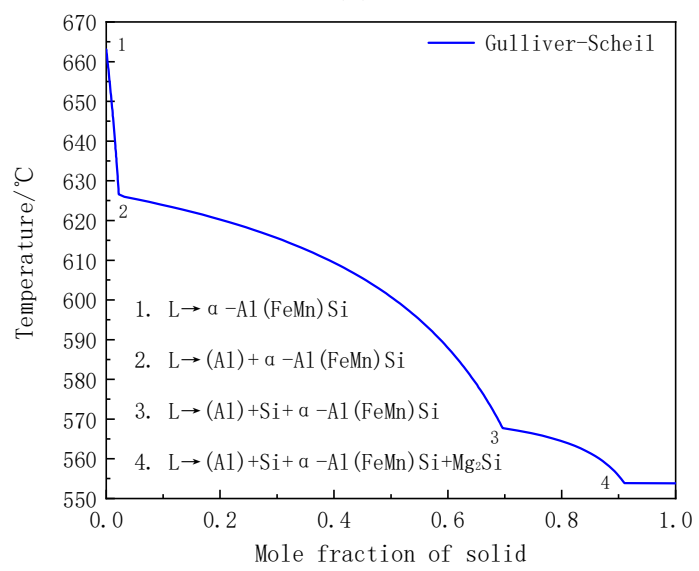

(e)

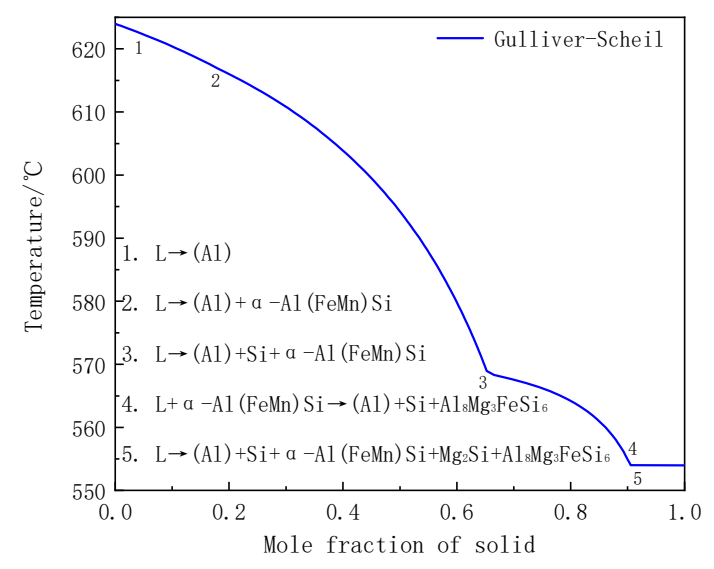

(b)

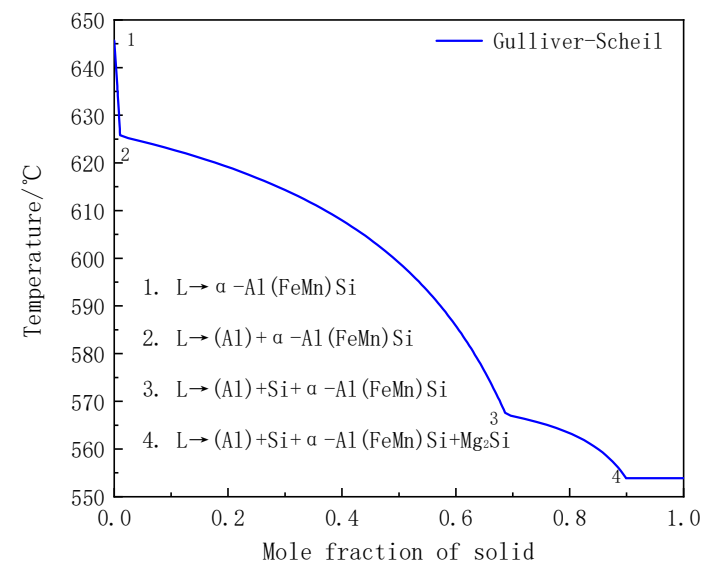

(d)

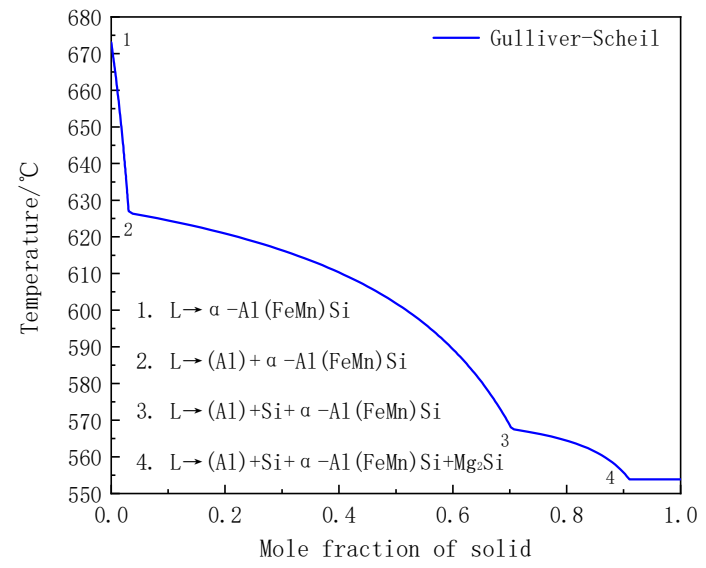

(f)

Figure 5. Calculated Solidification curves of Al-5Si-0.8Mg-xMn alloys under Gulliver-Scheil non-equilibrium conditions: (a) without Mn and with (b) $0.45 \% \mathrm{Mn}$, (c) $0.72 \% \mathrm{Mn}$, (d) $1.09 \% \mathrm{Mn}$, (e) $1.65 \% \mathrm{Mn}$ and (f) $1.97 \% \mathrm{Mn}$.

In conclusion, the addition of Mn changed the composition and morphology of the Fe phase in Al-5Si-0.8Mg alloy. The $\mathrm{Al}_{8} \mathrm{Mg}_{3} \mathrm{FeSi}_{6}$ phase almost disappeared and the eutectic $\alpha-\mathrm{Al}(\mathrm{FeMn}) \mathrm{Si}$ formed in Al-5Si-0.8Mg alloy when the Mn content increased to $0.45 \%$. At the same time, when the Mn content was up to $0.72 \%$, the primary $\alpha-\mathrm{Al}(\mathrm{FeMn}) \mathrm{Si}$ phase occurred during the solidification of Al-5Si-0.8Mg alloy, and the solidification reaction temperature of primary $\alpha-\mathrm{Al}(\mathrm{FeMn}) \mathrm{Si}$ phase gradually increased with the increasing Mn content. 
Table 3. Main reactions observed from the thermal analysis diagrams of the experimental alloys.

\begin{tabular}{|c|c|c|c|}
\hline Alloy & $\begin{array}{l}\text { Reaction } \\
\text { Number }\end{array}$ & $\begin{array}{c}\text { Temperature } \\
\left({ }^{\circ} \mathrm{C}\right)\end{array}$ & Type of Reaction \\
\hline \multirow{5}{*}{$1(0 \mathrm{Mn})$} & 1 & 621.7 & $\mathrm{~L} \rightarrow(\mathrm{Al})$ \\
\hline & 2 & 580.8 & $\mathrm{~L} \rightarrow(\mathrm{Al})+\mathrm{Al}_{5} \mathrm{FeSi}$ \\
\hline & 3 & 569.3 & $\mathrm{~L} \rightarrow(\mathrm{Al})+\mathrm{Si}+\mathrm{Al}_{5} \mathrm{FeSi}$ \\
\hline & 4 & 559.7 & $\mathrm{~L}+\mathrm{Al}_{5} \mathrm{FeSi} \rightarrow(\mathrm{Al})+\mathrm{Si}+\mathrm{Al}_{8} \mathrm{Mg}_{3} \mathrm{FeSi}_{6}$ \\
\hline & 5 & 554.2 & $\mathrm{~L} \rightarrow(\mathrm{Al})+\mathrm{Si}+\mathrm{Mg}_{2} \mathrm{Si}+\mathrm{Al}_{8} \mathrm{Mg}_{3} \mathrm{FeSi}_{6}$ \\
\hline \multirow{5}{*}{$2(0.45 \% \mathrm{Mn})$} & 1 & 624.0 & $\mathrm{~L} \rightarrow(\mathrm{Al})$ \\
\hline & 2 & 616.3 & $\mathrm{~L} \rightarrow(\mathrm{Al})+\alpha-\mathrm{Al}(\mathrm{FeMn}) \mathrm{Si}$ \\
\hline & 3 & 568.3 & $\mathrm{~L} \rightarrow(\mathrm{Al})+\mathrm{Si}+\alpha-\mathrm{Al}(\mathrm{FeMn}) \mathrm{Si}$ \\
\hline & 4 & 554.1 & $\mathrm{~L}+\alpha-\mathrm{Al}(\mathrm{FeMn}) \mathrm{Si} \rightarrow(\mathrm{Al})+\mathrm{Si}+\mathrm{Al}_{8} \mathrm{Mg}_{3} \mathrm{FeSi}_{6}$ \\
\hline & 5 & 554.0 & $\mathrm{~L} \rightarrow(\mathrm{Al})+\mathrm{Si}+\mathrm{Mg}_{2} \mathrm{Si}+\mathrm{Al}_{8} \mathrm{Mg}_{3} \mathrm{FeSi}_{6}+\alpha-\mathrm{Al}(\mathrm{FeMn}) \mathrm{Si}$ \\
\hline \multirow{4}{*}{$3(0.72 \% \mathrm{Mn})$} & 1 & 626.2 & $\mathrm{~L} \rightarrow \alpha-\mathrm{Al}(\mathrm{FeMn}) \mathrm{Si}$ \\
\hline & 2 & 624.9 & $\mathrm{~L} \rightarrow(\mathrm{Al})+\alpha-\mathrm{Al}(\mathrm{FeMn}) \mathrm{Si}$ \\
\hline & 3 & 567.3 & $\mathrm{~L} \rightarrow(\mathrm{Al})+\mathrm{Si}+\alpha-\mathrm{Al}(\mathrm{FeMn}) \mathrm{Si}$ \\
\hline & 4 & 553.8 & $\mathrm{~L} \rightarrow(\mathrm{Al})+\mathrm{Si}+\mathrm{Mg}_{2} \mathrm{Si}+\alpha-\mathrm{Al}(\mathrm{FeMn}) \mathrm{Si}$ \\
\hline \multirow{4}{*}{$4(1.09 \% \mathrm{Mn})$} & 1 & 645.7 & $\mathrm{~L} \rightarrow \alpha-\mathrm{Al}(\mathrm{FeMn}) \mathrm{Si}$ \\
\hline & 2 & 625.2 & $\mathrm{~L} \rightarrow(\mathrm{Al})+\alpha-\mathrm{Al}(\mathrm{FeMn}) \mathrm{Si}$ \\
\hline & 3 & 567.0 & $\mathrm{~L} \rightarrow(\mathrm{Al})+\mathrm{Si}+\alpha-\mathrm{Al}(\mathrm{FeMn}) \mathrm{Si}$ \\
\hline & 4 & 553.8 & $\mathrm{~L} \rightarrow(\mathrm{Al})+\mathrm{Si}+\mathrm{Mg}_{2} \mathrm{Si}+\alpha-\mathrm{Al}(\mathrm{FeMn}) \mathrm{Si}$ \\
\hline \multirow{4}{*}{$5(1.65 \% \mathrm{Mn})$} & 1 & 663.1 & $\mathrm{~L} \rightarrow \alpha-\mathrm{Al}(\mathrm{FeMn}) \mathrm{Si}$ \\
\hline & 2 & 626.0 & $\mathrm{~L} \rightarrow(\mathrm{Al})+\alpha-\mathrm{Al}(\mathrm{FeMn}) \mathrm{Si}$ \\
\hline & 3 & 567.1 & $\mathrm{~L} \rightarrow(\mathrm{Al})+\mathrm{Si}+\alpha-\mathrm{Al}(\mathrm{FeMn}) \mathrm{Si}$ \\
\hline & 4 & 553.8 & $\mathrm{~L} \rightarrow(\mathrm{Al})+\mathrm{Si}+\mathrm{Mg}_{2} \mathrm{Si}+\alpha-\mathrm{Al}(\mathrm{FeMn}) \mathrm{Si}$ \\
\hline \multirow{4}{*}{$6(1.97 \% \mathrm{Mn})$} & 1 & 673.1 & $\mathrm{~L} \rightarrow \alpha-\mathrm{Al}(\mathrm{FeMn}) \mathrm{Si}$ \\
\hline & 2 & 626.3 & $\mathrm{~L} \rightarrow(\mathrm{Al})+\alpha-\mathrm{Al}(\mathrm{FeMn}) \mathrm{Si}$ \\
\hline & 3 & 567.5 & $\mathrm{~L} \rightarrow(\mathrm{Al})+\mathrm{Si}+\alpha-\mathrm{Al}(\mathrm{FeMn}) \mathrm{Si}$ \\
\hline & 4 & 553.8 & $\mathrm{~L} \rightarrow(\mathrm{Al})+\mathrm{Si}+\mathrm{Mg}_{2} \mathrm{Si}+\alpha-\mathrm{Al}(\mathrm{FeMn}) \mathrm{Si}$ \\
\hline
\end{tabular}

It can be observed from Figures 2 and 5 that there were significant differences in the morphology of alloy phases among $\mathrm{Al}-5 \mathrm{Si}-0.8 \mathrm{Mg}$ alloys with different Mn contents. No obvious $\left(\alpha-\mathrm{Al}+\mathrm{Si}+\mathrm{Mg}_{2} \mathrm{Si}+\mathrm{Al}_{8} \mathrm{Mg}_{3} \mathrm{FeSi}_{6}\right)$ quaternary eutectic structure was observed in the $\mathrm{Mn}$-free $\mathrm{Al}-5 \mathrm{Si}-0.8 \mathrm{Mg}$ alloy, because most of the solution $\mathrm{Mg}$ atom in the alloy firstly formed the $\mathrm{Al}_{8} \mathrm{Mg}_{3} \mathrm{FeSi}_{6}$ phase, and there was a relatively small number of remaining $\mathrm{Mg}$ atoms to form $\mathrm{Mg}_{2} \mathrm{Si}$. During the reaction of $\mathrm{L} \rightarrow \alpha-\mathrm{Al}+\mathrm{Si}+\mathrm{Mg}_{2} \mathrm{Si}+\mathrm{Al}_{8} \mathrm{Mg}_{3} \mathrm{FeSi}_{6}$ in Mn-free Al-5Si-0.8Mg alloy, $\alpha-\mathrm{Al}$ and Si phases attached on the existing $\alpha-\mathrm{Al}$ and Si phases to nucleate and precipitate, and finally formed a very small amount of divorced blocky eutectic $\mathrm{Mg}_{2} \mathrm{Si}$ (as shown in the dashed area in Figure 4a).

When the amount of $\mathrm{Mn}$ was $0.45 \%$, the model calculation result showed that the mass fraction of $\mathrm{Al}_{8} \mathrm{Mg}_{3} \mathrm{FeSi}_{6}$ phase was only $0.001 \%$, which means that the $\mathrm{Al}_{8} \mathrm{Mg}_{3} \mathrm{FeSi}_{6}$

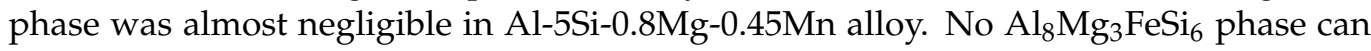
be observed in the microstructure (Figure $2 b$ ) or be analyzed in the XRD testing results (Figure 3). Additionally, there is no $\left(\alpha-\mathrm{Al}+\mathrm{Si}+\mathrm{Mg}_{2} \mathrm{Si}+\mathrm{Al}_{8} \mathrm{Mg}_{3} \mathrm{FeSi}_{6}+\alpha-\mathrm{Al}(\mathrm{FeMn}) \mathrm{Si}\right)$ quintet eutectic structure but $\left(\alpha-\mathrm{Al}+\mathrm{Si}+\mathrm{Mg}_{2} \mathrm{Si}+\alpha-\mathrm{Al}(\mathrm{FeMn}) \mathrm{Si}\right)$ quaternary eutectic structure can be observed in Al-5Si-0.8Mg-0.45Mn alloy (as shown in the dashed area in Figure $4 \mathrm{~b})$. In the meantime, the eutectic $\alpha-\mathrm{Al}(\mathrm{FeMn}) \mathrm{Si}$ appeared in $\mathrm{Al}-5 \mathrm{Si}-0.8 \mathrm{Mg}$ alloy when the Mn content increased to $0.45 \%$. Therefore, the calculation result is consistent with the experimental observations.

When the content of Mn reached $0.72 \%$, primary $\alpha-\mathrm{Al}(\mathrm{FeMn}) \mathrm{Si}$ occured by $\mathrm{L} \rightarrow \alpha-$ $\mathrm{Al}(\mathrm{FeMn}) \mathrm{Si}$, and the formation of the primary $\alpha-\mathrm{Al}(\mathrm{FeMn}) \mathrm{Si}$ phase relatively increased the concentration of solution $\mathrm{Mg}$ atom at the interface between liquid phase and $\alpha-\mathrm{Al}(\mathrm{FeMn}) \mathrm{Si}$ phase, which was conducive to the formation of $\left(\alpha-\mathrm{Al}+\mathrm{Si}+\mathrm{Mg}_{2} \mathrm{Si}+\alpha-\mathrm{Al}(\mathrm{FeMn}) \mathrm{Si}\right)$ quaternary eutectic structure. Therefore, a large number of lamellar $\left(\alpha-\mathrm{Al}+\mathrm{Si}+\mathrm{Mg}_{2} \mathrm{Si}+\alpha-\right.$ $\mathrm{Al}(\mathrm{FeMn}) \mathrm{Si}$ ) quaternary eutectic structure was observed in the alloy, as shown in the 
solid area in Figure 2c. The solidification reactions remained unchanged but the $(\alpha-$ $\left.\mathrm{Al}+\mathrm{Si}+\mathrm{Mg}_{2} \mathrm{Si}+\alpha-\mathrm{Al}(\mathrm{FeMn}) \mathrm{Si}\right)$ quaternary eutectic structure was significantly refined as the Mn content increased to $1.97 \%$ (as shown in the dashed area in Figure $5 \mathrm{c}$ ). The $\mathrm{Mg}$ content at the solid-liquid interfaces relatively increased due to the precipitating from the solidification of primary $\alpha-\mathrm{Al}(\mathrm{FeMn}) \mathrm{Si}$ and eutectic $\alpha-\mathrm{Al}(\mathrm{FeMn}) \mathrm{Si}$, which results in the increase in the constitutional supercooling of the alloy. This is the main reason that the phenomenon of divorced eutectic $\mathrm{Mg}_{2} \mathrm{Si}$ is weakened, and the quaternary eutectic structure is gradually refined during the solidification of $\mathrm{Al}-5 \mathrm{Si}-0.8 \mathrm{Mg}$ aluminum alloys with the increase in Mn content from $0.72 \%$ to $1.97 \%$. Furthermore, with the increase in Mn content from $0.72 \%$ to $1.97 \%$, the reaction temperature of $\mathrm{L} \rightarrow \alpha-\mathrm{Al}(\mathrm{FeMn}) \mathrm{Si}$ gradually increased from 626.2 to $673.1^{\circ} \mathrm{C}$, which is the main cause to the gradual increase in size and number of the primary $\alpha-\mathrm{Al}(\mathrm{FeMn}) \mathrm{Si}$ phase.

In addition, the $\mathrm{L} \rightarrow \alpha$-Al reaction has been replaced by the $\mathrm{L} \rightarrow \alpha-\mathrm{Al}+\alpha-\mathrm{Al}(\mathrm{FeMn}) \mathrm{Si}$ reaction in the solidification of Al-5Si- $0.8 \mathrm{Mg}$ alloy when $\mathrm{Mn}$ was added more than $0.72 \%$, and all of the $\alpha-\mathrm{Al}$ in Al-5Si-0.8Mg-(0.72-1.97)Mn alloys (as shown in Figures 2 and 5) was eutectic structure with a few eutectic morphology characteristics, due to the relative content of $\alpha-\mathrm{Al}$ was about 30 times of that of $\alpha-\mathrm{Al}(\mathrm{FeMn}) \mathrm{Si}$ by the reaction of $\mathrm{L} \rightarrow \alpha-\mathrm{Al}+$ $\alpha-\mathrm{Al}(\mathrm{FeMn}) \mathrm{Si}$, according to the calculated results. Therefore, with the addition of $\mathrm{Mn}$ up to $0.72 \%$, the microstructure of $\alpha-\mathrm{Al}$ in the $\mathrm{Al}-5 \mathrm{Si}-0.8 \mathrm{Mg}$ alloys formed by eutectic reactions.

\section{Conclusions}

(1) There are $\alpha-\mathrm{Al}, \mathrm{Si}, \mathrm{Mg}_{2} \mathrm{Si}$ and $\pi\left(\mathrm{Al}_{8} \mathrm{Mg}_{3} \mathrm{FeSi}_{6}\right)$ in the $\mathrm{Mn}$-free $\mathrm{Al}-5 \mathrm{Si}-0.8 \mathrm{Mg}$ alloy ingot while most of the $\pi\left(\mathrm{Al}_{8} \mathrm{Mg}_{3} \mathrm{FeSi}_{6}\right)$ phase disappeared and the $\alpha-\mathrm{Al}(\mathrm{FeMn}) \mathrm{Si}$ phase formed in $\mathrm{Al}-5 \mathrm{Si}-0.8 \mathrm{Mg}-0.45 \mathrm{Mn}$ alloy ingot.

(2) Starting from $0.72 \% \mathrm{Mn}$, the first reaction is changed from $\mathrm{L} \rightarrow \alpha-\mathrm{Al}$ to $\mathrm{L} \rightarrow \alpha-\mathrm{Al}(\mathrm{FeMn}) \mathrm{Si}$ with the presence of the primary $\alpha-\mathrm{Al}(\mathrm{FeMn}) \mathrm{Si}$ phase.

(3) With the increasing of Mn content from $0.72 \%$ to $1.97 \%$, the solidification reactions remained unchanged, whereas, the size and number of the primary $\alpha-\mathrm{Al}(\mathrm{FeMn}) \mathrm{Si}$ phase gradually increased. While the divorced eutectic phenomenon of quaternary eutectic structure gradually weakened, the $\mathrm{Mg}_{2} \mathrm{Si}$ phase in the quaternary eutectic structure gradually transformed from blocky to fine eutectic lamellar, and the quaternary eutectic structure was significantly refined.

(4) All of the $\alpha$-Al in Al-5Si-0.8Mg aluminum alloys with the Mn additions higher than $0.72 \%$ were eutectic structure with few eutectic morphology characteristics.

Author Contributions: N.T. and G.W. designed the experiments and wrote this manuscript. Y.Z. helped with the experiments and the analysis of the experimental data. C.L. prepared the specimens, K.L. reviewed and edited the manuscript. G.Z. and L.Z. gave some constructive suggestions. All authors have read and agreed to the published version of the manuscript.

Funding: This work was financially supported by the National Natural Science Foundation of China (51871043), Fundamental Research Funds for the Central Universities of China (N180212010), Liaoning Natural Science Foundation Project of China (2019-MS-113) and National Key R\&D Program of China (2016YFB0300801).

Data Availability Statement: Not applicable.

Acknowledgments: The authors additionally acknowledge the work of Chong Li for the initial work on performing the fundamental experiments.

Conflicts of Interest: The authors declare no conflict of interest. 


\section{References}

1. $\quad$ Liang, J.M.; Kong, C.; Quadir, M.Z.; Zheng, Y.F.; Yao, X.; Munroe, P.; Zhang, D.L. Microstructure and mechanical properties of a bulk ultrafine grained Al-7Si-0.3Mg alloy produced by thermomechanical consolidation of a nanocrystalline powder. Mater. Sci. Eng. A 2016, 658, 192-202. [CrossRef]

2. Chen, J.; Poole, W.J.; Parson, N.C. The effect of through thickness texture variation on the anisotropic mechanical response of an extruded Al-Mn-Fe-Si alloy. Mater. Sci. Eng. A 2018, 730, 24-35. [CrossRef]

3. Shaha, S.K.; Czerwinski, F.; Kasprzak, W.; Friedman, J.; Chen, D.L. Effect of Mn and heat treatment on improvements in static strength and low-cycle fatigue life of an Al-Si-Cu-Mg alloy. Mater. Sci. Eng. A 2016, 657, 441-452. [CrossRef]

4. Cai, Y.; Liang, R.; Hou, L.; Zhang, J. Effect of $\mathrm{Cr}$ and Mn on the microstructure of spray-formed Al-25Si-5Fe-3Cu alloy. Mater. Sci. Eng. A. 2011, 528, 4248-4254. [CrossRef]

5. Bolzoni, L.; Nowak, M.; Hari Babu, N. Grain refining potency of Nb-B inoculation on Al-12Si-0.6Fe-0.5Mn alloy. J. Alloy. Compd. 2015, 623, 79-82. [CrossRef]

6. Karlík, M.; Mánik, T.; Lauschmann, H. Influence of Si and Fe on the distribution of intermetallic compounds in twin-roll cast Al-Mn-Zr alloys. J. Alloy. Compd. 2012, 515, 108-113. [CrossRef]

7. Qiu, K.; Wang, R.C.; Peng, C.Q.; Wang, N.G.; Cai, Z.Y.; Zhang, C. Effects of Mn and Sn on microstructure of Al-7Si-Mg alloy modified by Sr and Al-Ti-B. Trans. Nonferrous Met. Soc. China 2015, 25, 3546-3552. [CrossRef]

8. Huang, H.J.; Cai, Y.H.; Cui, H.; Huang, J.F.; He, J.P.; Zhang, J.S. Influence of Mn addition on microstructure and phase formation of spray-deposited Al-25Si-xFe-yMn alloy. Mater. Sci. Eng. A 2009, 502, 118-125. [CrossRef]

9. Salem, S.; Sten, J.; Ingvar, L. The influence of cooling rate and manganese content on the $\beta$-Al5FeSi phase formation and mechanical properties of Al-Si-based alloys. Mater. Sci. Eng. A 2008, 490, 385-390.

10. Hwang, J.Y.; Doty, H.W.; Kaufman, M.J. The effects of Mn additions on the microstructure and mechanical properties of Al-Si-Cu casting alloys. Mater. Sci. Eng. A 2008, 488, 496-504. [CrossRef]

11. Wang, F.; Zhang, J.; Xiong, B.; Zhang, Y. Effect of Fe and Mn additions on microstructure and mechanical properties of spraydeposited Al-20Si-3Cu-1Mg alloy. Mater. Charact. 2009, 60, 384-388. [CrossRef]

12. Wang, E.R.; Hui, X.D.; Chen, G.L. Eutectic Al-Si-Cu-Fe-Mn alloys with enhanced mechanical properties at room and elevated temperature. Mater. Des. 2011, 32, 4333-4340. [CrossRef]

13. Lu, D.; Jiang, Y.; Guan, G.; Zhou, R.; Li, Z.; Zhou, R. Refinement of primary Si in hypereutectic Al-Si alloy by electromagnetic stirring. J. Mater. Process. Technol. 2007, 189, 13-18. [CrossRef]

14. Lin, C.; Wu, S.; Lü, S.; An, P.; Wan, L. Effects of ultrasonic vibration and manganese on microstructure and mechanical properties of hypereutectic Al-Si alloys with 2\% Fe. Intermetallic 2013, 32, 176-183. [CrossRef]

15. Stefano, F.; Anton, B.; Salem, S. On the Formation of Sludge Intermetallic Particles in Secondary Aluminum Alloys. Metall. Mater. Trans. A 2015, 46, 3713-3722.

16. Giulio, T.; Stefano, C.; Alberto, F. Precipitation of primary Fe-rich compounds in secondary AlSi9Cu3(Fe) alloys. J. Therm. Anal. Calorim. 2015, 123, 249-262.

17. Liu, Y.L.; Kang, S.B. The solidification process of Al-Mg-Si alloys. J. Mater. Sci. 1997, 32, 1443-1447. [CrossRef]

18. Yan, L.Z.; Zhang, Y.A.; Li, X.W.; Li, Z.H.; Feng, W.A.N.G.; Liu, H.W.; Xiong, B.Q. Microstructural evolution of Al-0.66Mg-0.85Si alloy during homogenization. Trans. Nonferrous Met. Soc. China 2014, 24, 939-945. [CrossRef]

19. Lee, D.H.; Park, J.H.; Nam, S.W. Enhancement of mechanical properties of Al-Mg-Si alloys by means of manganese dispersoid. Mater. Sci. Technol. 1999, 15, 450-455. [CrossRef]

20. Han, Y.; Ma, K.; Li, L.; Chen, W.; Nagaumi, H. Study on microstructure and mechanical properties of Al-Mg-Si-Cu alloy with high manganese content. Mater. Des. 2012, 39, 418-424. [CrossRef]

21. Backerud, L.; Chai, G.; Tamminen, J. Solidification Characteristics of Aluminium Alloys; AFS/Skanaluminum: Oslo, Norway, 1990; pp. 71-84. 